Article

\title{
A Cassette Vector System for the Rapid Cloning and Production of Bispecific Tetravalent Antibodies
}

\author{
Stefanie Claudia Pohl, Steffi Schwarz, André Frenzel and Thomas Schirrmann * \\ Department of Biotechnology, Technische Universität Braunschweig, Spielmannstr. 7, \\ 38106 Braunschweig, Germany; E-Mails: stefanie.pohl@twincore.de (S.C.P.); \\ steffischwarz2@gmx.de (S.S.); andre.frenzel@tu-bs.de (A.F.) \\ * Author to whom correspondence should be addressed; E-Mail: th.schirrmann@tu-bs.de; \\ Tel.: +49-531-391-5760; Fax: +49-531-391-5763.
}

Received: 1 March 2012; in revised form: 28 March 2012 / Accepted: 30 March 2012 / Published: 11 April 2012

\begin{abstract}
Bivalent single chain (sc)Fv-Fc antibodies have been used for years as recombinant alternatives of natural immunoglobulins. We have extended this approach to the scFv-Fc-scFv antibody format to obtain tetravalent antigen binding and the possibility to generate bispecific antibodies. We developed a mammalian expression vector system to construct tetravalent scFv-Fc-scFv antibodies with two NcoI+NotI compatible cloning sites flanking the Fe gene fragment. We demonstrated direct cloning from single chain antibody gene libraries and tested various scFv combinations. Transient production of scFv-Fc-scFv antibodies in human embryonic kidney (HEK) 293T cells achieved volumetric yields of up to $10 \mathrm{mg} / \mathrm{L}$. However, expression levels were strongly dependent on the carboxyterminal scFv and the scFv combination. All scFv-Fc-scFv antibodies exclusively formed disulfide-linked homodimers. Antigen binding studies revealed dual specificity for all $\mathrm{scFv}-\mathrm{Fc}-\mathrm{scFv}$ employing different $\mathrm{scFv}$ fragments. Comparison of C-reactive protein (CRP) specific monovalent scFv LA13-IIE3, bivalent scFv-Fc and Fc-scFv LA13-IIE3, and tetravalent scFv-Fc-scFv (scFv LA13-IIE3 in combination with scFvs LA13-IIE3, TOB4-B11, or TOB5-D4) revealed an up to 500-fold increased antigen binding. This novel scFv-Fc-scFv antibody expression system allows simple and fast testing of various scFv combinations.
\end{abstract}

Keywords: recombinant antibody; single chain $\mathrm{Fv}$; $\mathrm{scFv}-\mathrm{Fc}-\mathrm{scFv}$; bispecific antibody; tetravalent antibody, dual specificity; mammalian expression 


\section{Introduction}

In vitro selection technologies can dramatically increase the throughput of the generation of human recombinant antibodies [1]. These antibodies can be further improved by antibody engineering, for example by in vitro affinity and stability maturation $[2,3]$ or by transferring them into multimeric antibody formats [4-7]. Moreover, combining two different antibodies into one bispecific molecule allows new applications which benefit from dual antigen binding. These bispecific antibodies (bsAbs) are particularly interesting in the field of antibody therapy, for example to retarget immune cells to tumor cells [8-10], to inhibit virus entry into host cells [11], to simultaneously inhibit different physiological pathways [12] or to direct cytotoxic agents to target cells [13]. To date, more than 40 different bsAb formats have been described [14]. The first clinically approved bsAb is still generated by quadroma technology [15], but recombinant bsAbs are already tested in late clinical trials with very promising results [16]. Recombinant immunoglobulin (Ig)G like bsAb formats have the additional advantage of accessing the broad landscape of mammalian production systems, tag free purification systems and secondary detection reagents, which have been established for therapeutic IgGs for many years. CrossMabs [17] and SEEDbodies [18] can be designed to be almost indistinguishable from normal $\mathrm{IgG}$, but correct pairing of two different heavy and light chains requires long optimization to obtain high product homogeneity and to avoid non-functional side products. This problem can be overcome by fusing two different $\mathrm{scFv}$ fragments to light and heavy chain constant Ig regions [19,20], by fusing one $\mathrm{scFv}$ fragment to a functional full $\operatorname{IgG}[11,21,22]$, or by fusing two scFvs to the Fc moiety like in single chain diabody ( $\mathrm{scDb}$ )-Fc [23], tandem scFv-Fc [24], and scFv-FcscFv antibodies [12]. These tetravalent IgG-like bsAbs can mediate bivalent binding of both antigens which was found to be a thousand fold more effective in directing cytotoxicity of lymphokine-activated killer cells to tumor cells compared to bispecific diabody fragments [19]. Moreover, scFv-Fc-scFv antibodies were successfully used to simultaneously neutralize two different cytokines [25], to attenuate angiogenesis through two distinct pathways [12], or to knock down two endothelial transmembrane receptors [26].

Despite the success of bsAbs, there is no vector platform available that can provide simple cloning procedures, compatibility to antibody gene libraries, efficient production and purification to reduce the tremendous efforts required for combinatory testing of large numbers of different antibody fragments in a bispecific format. In this study, we developed a simple two-step cloning system for generating tetravalent IgG-like bsAbs (Figure 1A) from single chain antibodies which provides compatibility to established antibody gene libraries as well as to IgG production and purification systems.

\section{Results and Discussion}

\subsection{Construction of Mammalian Expression Vectors for the Production of $s c F v-F c-s c F v$ Antibodies}

The vectors pCMV2.2- and pCMV5.2-hIgG1Fc-XP (Figure 1B) were derived from the previously described plasmid pCMV-hIgG1Fc-XP [6]. Both vectors contain the same NcoI+NotI cloning sites between leader sequence and the gene fragment encoding the human IgG1, including constant hinge, $\mathrm{CH} 2$ and $\mathrm{CH} 3$ regions. The leader sequence encodes the secretory mouse immunoglobulin heavy chain signal peptide consisting of two exons (E1, E2) and its natural intron (I) for stabilized gene expression. 
The following NcoI+NotI cloning sites allow single step in frame cloning of single chain Fv gene fragments from the human naïve antibody gene libraries HAL4, 7 and 8 [1] and from several other single chain antibody phage display libraries. Expression of the antibody gene cassette is driven by the human immediate early cytomegalovirus (CMV) promoter and terminated by the bovine growth hormone $(\mathrm{BGH})$ poly A signal sequence $(\mathrm{pA})$. The vectors pCMV2.2- and pCMV5.2-hIgG1Fc-XP differ only at the $3^{\prime}$ terminus of the human IgG1 Fc gene fragment. The vector pCMV2.2-hIgG1Fc-XP contains a strong stop codon resulting in scFv-Fc antibody constructs, whereas in vector pCMV5.2hIgG1Fc-XP the $3^{\prime}$ end of Fc gene fragment is fused to a sequence encoding a flexible and soluble spacer of eight amino acids (GCGGGTSG) followed by a second cloning cassette formed by two $B s m B I$ class II subtype $\mathrm{S}$ restriction sites. A stop codon is inserted between both BsmBI sites. Cutting both $B \operatorname{smBI}$ sites result in $N \operatorname{coI}+N o t \mathrm{I}$ compatible four nucleotides overhangs which allow single step cloning from the same antibody gene libraries as mentioned above (Figure 1). Since BsmBI sites frequently occur in human antibody genes (one is frequently present in human $\mathrm{VH}$; data not shown) it is usually necessary to start cloning with the $3^{\prime}$ scFv2 gene fragment encoding the carboxyterminal $\mathrm{scFv}$ moiety. After ligation, the $N$ coI $+N o t \mathrm{I}$ sites flanking the parental $\mathrm{scFv}$ gene fragments are destroyed and a new stop codon occurs by frame shift at the $3^{\prime}$ end of the gene construct. The NcoI compatible overhang results in two additional amino acids (namely: MA) between spacer and scFv, whereas the NotI compatible overhang attaches two alanine codons to the carboxyterminus. Moreover, the NcoI+NotI cloning sites at the $5^{\prime}$ end of the Fc fragment can be still used for cloning of the scFv1 gene fragment which will be encoded at the aminoterminus of Fc moiety. Cloning of both scFv gene fragments in this order was efficiently performed, resulting in a large number scFv-Fc-scFv antibodies with various of $\mathrm{scFv}$ combinations, including the 2-phenyl-2-oxazoline-5-on (PhOx) specific scFv PhOx(-Yol), the CRP specific scFvs LA13-IIE3, TOB4-B11, TOB5-D4 and LA13-IID4, or a carcinoembryonic antigen (CEA) specific scFv derived from the humanized antibody BW431/26 [27] and a CD33-specific scFv constructed from the humanized antibody HuM195 [28].

\subsection{Production of $s c F v-F c-s c F v s$ Depends on the Employed $s c F v$ Domains}

Transient production of scFv-Fc-scFv antibodies was performed in human embryonic kidney (HEK) $293 \mathrm{~T}$ cells resulting in volumetric yields of several $\mathrm{mg} / \mathrm{L}$ for most of the constructs (Figure 2). The scFv-Fc antibodies containing only the aminoterminal scFv (PhOx and LA13-IIE3) showed high expression levels of about $25-30 \mu \mathrm{g} / \mathrm{mL}$. It should be noticed that during transient production the medium had to be harvested and exchanged every day, so that no product accumulation was achieved over several days. The yields can double if supernatants are harvested after two days, but enhanced cell death shortens the overall production time (data not shown). Generally, Fc-scFv and scFv-Fc-scFv antibodies showed lower yields than scFv-Fc antibodies. The volumetric yields of the Fc-scFv antibodies were still about $10-20 \mu \mathrm{g} / \mathrm{mL}$, except for the construct containing scFv BW431/26. The tetravalent scFv-Fc-scFv antibodies were produced with up to $10 \mu \mathrm{g} / \mathrm{mL}$ volumetric yield. The yield of different $\mathrm{scFv}-\mathrm{Fc}-\mathrm{scFv}$ antibodies was strongly dependent on the $\mathrm{scFv}$ fragment fused to the carboxyterminus and relatively independent of the aminoterminal scFv. Nevertheless, constructs with aminoterminal scFv PhOx tended to be produced less than those with the scFv LA13-IIE3 at this position. All antibody constructs containing CEA specific scFv BW431/26 including scFv-Fc (data not 
shown) were only marginally expressed compared to the other constructs and omitted from further studies. Interestingly, the combination of PhOx or LA13-IIE3 with themselves in scFv-Fc-scFv also resulted only in very low production $(1-2 \mu \mathrm{g} / \mathrm{mL})$. Generally, it can be concluded that the expression levels of scFv-Fc-scFv strongly depended on the employed scFv domains and the scFv combinations. In future studies, the use of suspension adapted production cell lines in combination with optimized media and production processes is expected to yield much higher production levels [6].

Figure 1. Schematic illustration of the $\mathrm{scFv}-\mathrm{Fc}-\mathrm{scFv}$ antibody format and the pCMV5.2hIgG1Fc-XP vector. This mammalian expression vector contains a $\mathrm{pCMV} / \mathrm{myc} / \mathrm{ER}$ plasmid backbone, including the beta-lactamase (bla) gene, the pMB1 bacterial origin of replication (ori), the neomycin phosphotransferase (neo) expression cassette with simian virus (SV) 40 promoter/ori and poly A signal (pA) as well as an F1 phage origin. The antibody expression cassette is driven by a human CMV promoter and terminated by a bovine growth hormone $(\mathrm{BGH}) \mathrm{pA}$. The antibody gene constructs contain a leader sequence (SP) which consists of two exons (E1, E2) interrupted by an intron (I) for stabilized gene expression. The leader sequence is followed by an NcoI+NotI cloning cassette for the aminoterminal scFv1. Downstream there are gene fragments encoding the hinge $(\mathrm{H})$, constant $\mathrm{CH} 2$ and $\mathrm{CH} 3$ regions of human IgG1-Fc and a short spacer sequence (S) followed by a second NcoI+NotI compatible cloning site formed by two BsmBI sites for the carboxyterminal scFv2. ScFv antibody fragments consist of variable heavy $\left(\mathrm{V}_{\mathrm{H}}\right)$ and light $\left(\mathrm{V}_{\mathrm{L}}\right)$ chains connected by soluble flexible linkers of at least 15 amino acids $(\mathrm{L})$. The schemes are not drawn to scale.

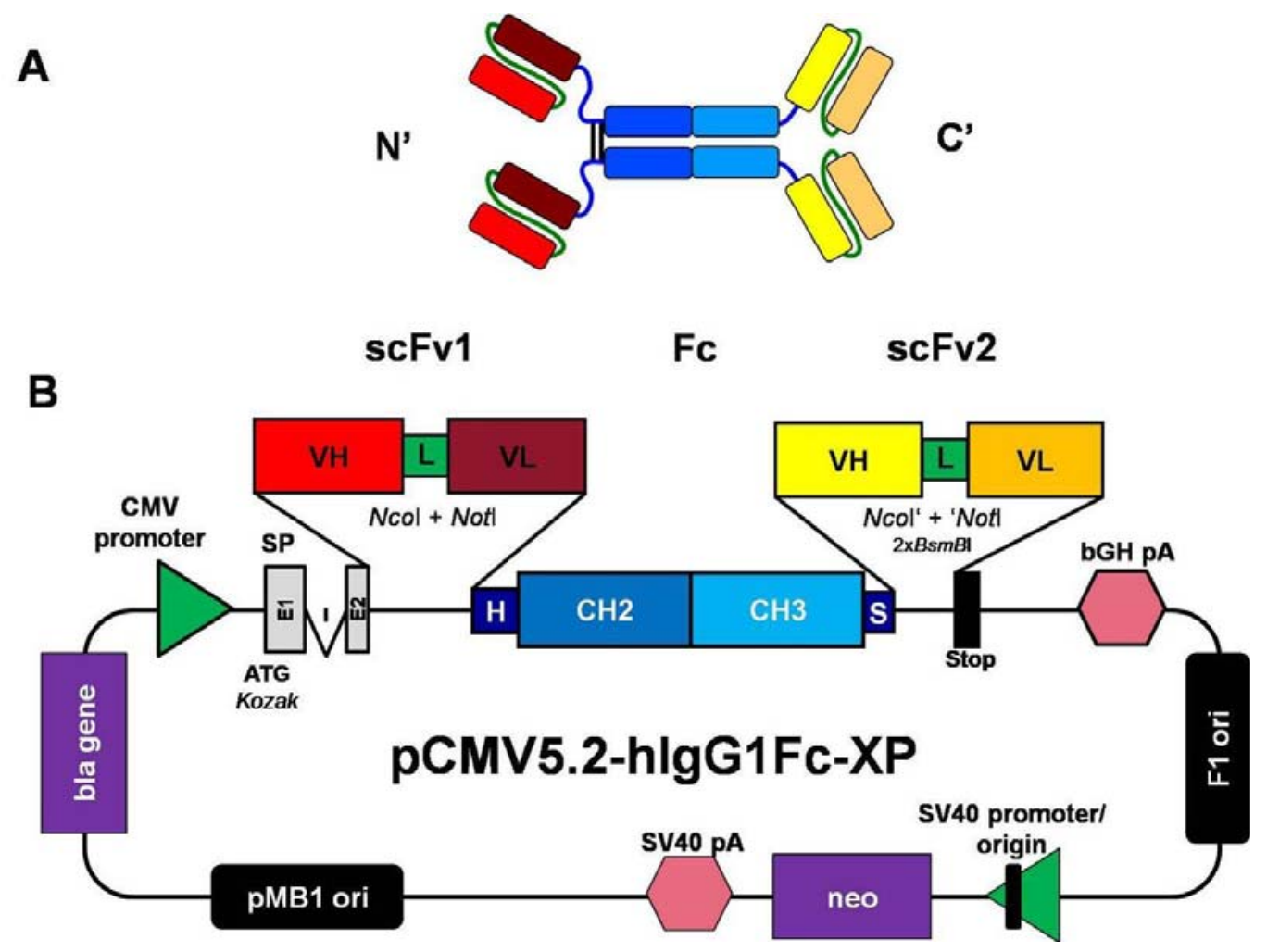


Figure 2. Volumetric yields of transient production of scFv-Fc, Fc-scFv and scFv-Fc-scFv antibodies in HEK293T cells. Production supernatants were analyzed by human $\mathrm{IgG} / \mathrm{Fc}$ capture enzyme immunosorbent assay (ELISA).

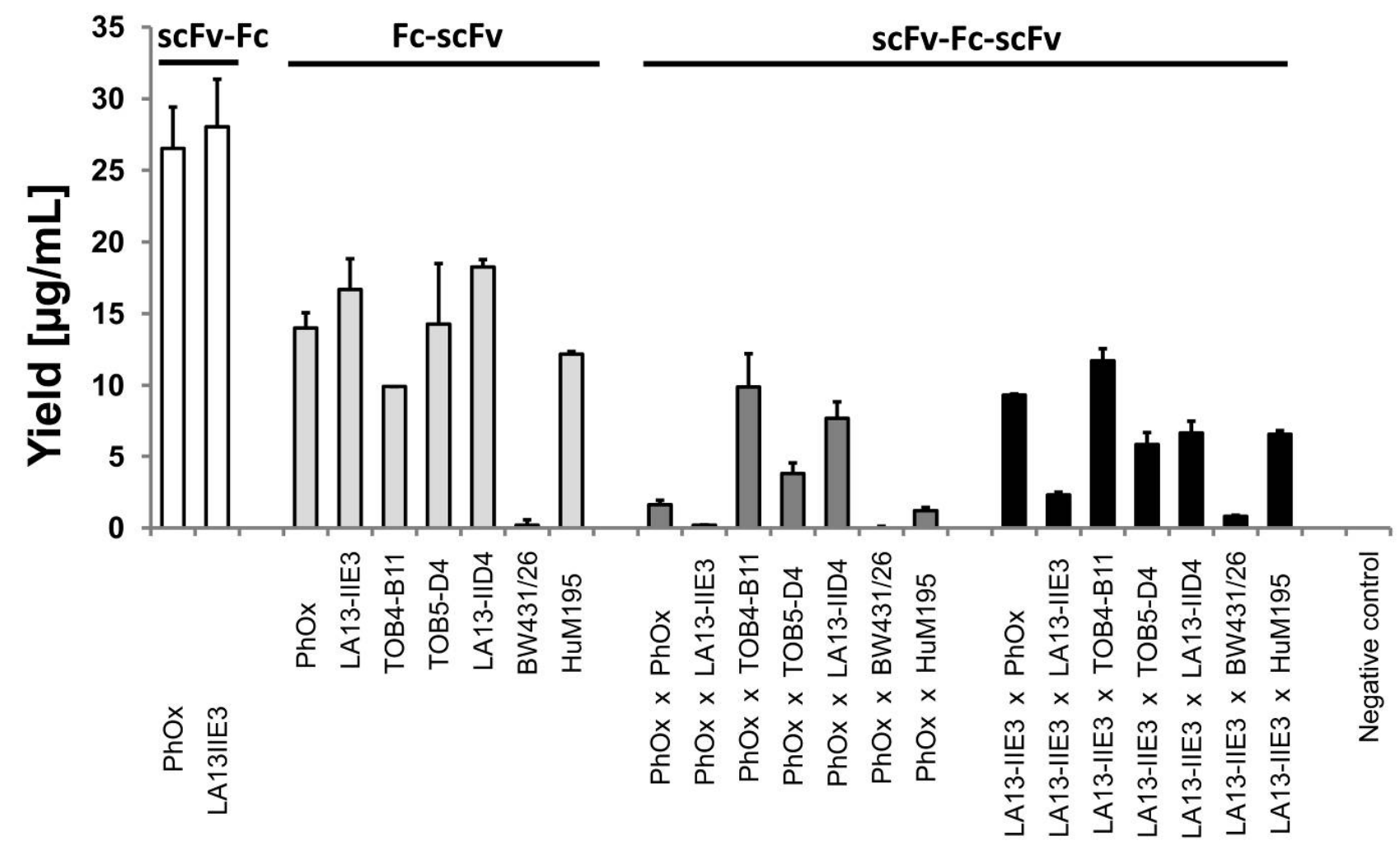

\section{scFv domains}

\section{3. $S c F v, F c-s c F v$ and $s c F v-F c-s c F v$ Antibodies Exclusively form Homodimers}

All produced scFv-Fc, Fc-scFv and scFv-Fc-scFv antibodies were purified using protein A magnetic beads or by protein A affinity chromatography. Sodium dodecyl sulfate (SDS) polyacrylamide gelelectrophoresis (PAGE) under reducing conditions revealed single or closely collocated double protein bands according to the expected molar mass (Figure 3A, Table 1). Co-purification of other proteins from the production culture supernatant was not observed. Under non-reducing conditions, all constructs migrated more than twice the molar mass of the single polypeptide chain (Table 1), indicating complete assembly of both chains to disulfide stabilized multimers (Figure 3B). Fc-scFv proteins migrated at about 105-110 kDa (Figure 3B) which is exactly the molar mass of homodimers (Table 1). In contrast, scFv-Fc antibodies revealed under non-reducing conditions in SDS-PAGE apparent molar masses of about $150 \mathrm{kDa}$ (Figure 3B) which is approximately 1.5-fold higher than observed for the Fc-scFv, although these polypeptides share almost the same theoretical molar mass (Table 1). Under non-reducing conditions, the scFv-Fc-scFv antibodies even migrated with apparent molar masses of more than $250 \mathrm{kDa}$ (Figure 3B) which is almost twice as much as the expected 155-165 kDa calculated from the amino acid sequences of their homodimeric forms (Table 1). The different position of the hinge region and its interchain disulfide bonds is the most noticeable difference of the Fc-scFv constructs compared to scFv-Fc and scFv-Fc-scFv. The hinge interchain disulfide bonds of Fc-scFv antibodies is located near the aminoterminus and do not interfere with the 
formation of a consecutive globular SDS protein complex and regular electrophoretic mobility under non-reducing conditions. In contrast, the interchain disulfide bonds in the centrally located hinge region of scFv-Fc and scFv-Fc-scFv antibodies seem to prevent the formation of a globular shaped consecutive SDS protein complex which results in lower electrophoretic migration and in higher apparent molar mass. Atypical electrophoretic mobility in SDS-PAGE under non-reducing conditions has been observed for full IgGs or single chain IgGs [7,29,30] and for some proteins even under reducing conditions, for example for the bacteriophage coat protein pIII [31]. However, the intensity of this effect can vary upon applied conditions for sample preparation, used buffers as well as SDS and polyacrylamide concentration.

Figure 3. SDS-PAGE of $100 \mathrm{ng}$ of protein A purified scFv-Fc, Fc-scFv or scFv-Fc-scFv antibodies prepared under (A) reducing and (B) non-reducing conditions. After electrophoresis polyacrylamide gels were silver stained. The $\mathrm{scFv}$ domains and their position regarding the Fc moiety are indicated for each construct.

A

Reducing conditions

Fc-scFv scFv-Fc scFv-Fc-scFv scFv-Fc scFv-Fc-scFv

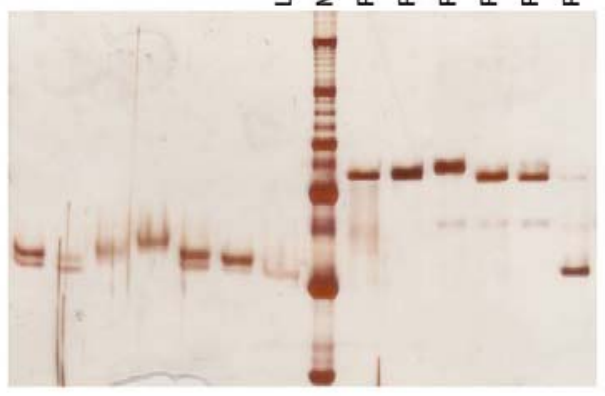

- 150 -

-100 -

-75 -

-50 -

- 37 -

B

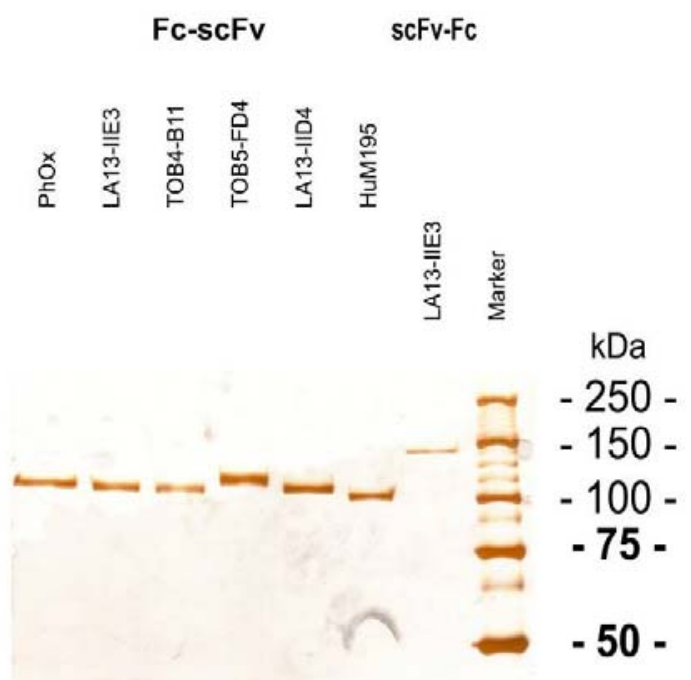

scFv-Fc-scFv scFv-Fc scFv-Fc-scFv

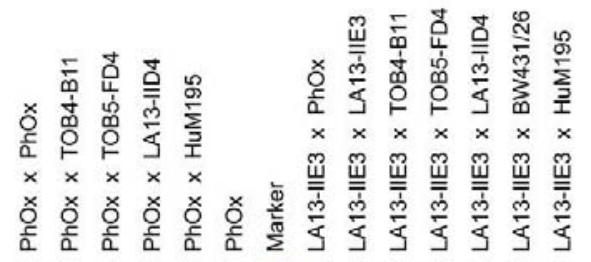


Table 1. Molar masses of LA13-IIE3 based scFv-Fc, Fc-scFv and scFv-Fc-scFv antibodies calculated from the amino acid sequences (for monomer and homodimer) and from retention volumes (Ve) measured by SEC.

\begin{tabular}{|c|c|c|c|c|c|c|}
\hline \multirow[b]{2}{*}{ Construct } & \multirow[b]{2}{*}{ scFv1 } & \multirow[b]{2}{*}{$\times$ scFv2 } & \multicolumn{2}{|c|}{ Theoretical molar mass } & \multirow[b]{2}{*}{\begin{tabular}{|l} 
Ve \\
{$[\mathrm{mL}]$}
\end{tabular}} & \multirow{2}{*}{$\begin{array}{l}\text { SEC } \\
\text { Molar } \\
\text { mass [kDa] }\end{array}$} \\
\hline & & & $\begin{array}{l}\text { Monomer } \\
\text { [kDa] }\end{array}$ & $\begin{array}{l}\text { Homodimer } \\
\text { [kDa] }\end{array}$ & & \\
\hline $\mathrm{scFv-Fc}$ & LA13-IIE3 & & 51.9 & 103.8 & 14.4 & 112.4 \\
\hline Fc-scFv & & LA13-IIE3 & 53.8 & 107.7 & 14.3 & 115.1 \\
\hline scFv-Fc-scFv & LA13-IIE3 & $\times$ LA13-IIE3 & 78.2 & 156.4 & 12.5 & 175.4 \\
\hline $\mathrm{scFv}-\mathrm{Fc}-\mathrm{scFv}$ & LA13-IIE3 & $\times$ TOB4-B11 & 79.6 & 159.2 & 12.4 & 179.5 \\
\hline $\mathrm{scFv}-\mathrm{Fc}-\mathrm{scFv}$ & LA13-IIE3 & $\times$ TOB5-D4 & 81.4 & 162.7 & 12.5 & 175.4 \\
\hline
\end{tabular}

Analytical size exclusion chromatography (SEC) of the scFv-Fc LA13-IIE3, Fc-scFv LA13-IIE3 as well as of the scFv-Fc-scFv antibodies LA13-IIE3 $\times$ LA13-IIE3, LA13-IIE3 $\times$ TOB4-B11 and LA13-IIE3 $\times$ TOB5-D4 confirmed that these antibodies exclusively form homodimers (Figure 4). The single peak of the protein fraction appeared at a retention volume (Ve) corresponding with molar masses of 112 and $115 \mathrm{kDa}$ for the scFv-Fc and Fc-scFv, respectively, and 175-180 kDa for the scFv-Fc-scFv antibodies which corresponds well with their homodimeric form (Table 1). The slightly higher molar masses can be expected from glycosylation in the Fc moiety. Mabry and colleagues [12] also measured only the homodimeric form of their scFv-Fc-scFv antibody by size-exclusion chromatography, combined with multi-angle light scattering (SEC-MALS). Their scFv-Fc-scFv construct was even less prone to aggregation at high concentrations than the parental scFv fragments.

\section{4. $S c F v-F c-s c F v$ Antibodies Provide Dual Antigen Specificity}

Specific binding to CRP and the hapten $\mathrm{PhOx}$ (PhOx-BSA) was tested for all scFv-Fc, Fc-scFv and scFv-Fc-scFv antibodies using an indirect antigen ELISA (Figure 5). All antibodies containing the scFv PhOx showed binding to PhOx-BSA whereas those which contained at least one of the following scFvs LA13-IIE3, TOB4-B11, TOB5-D4 and LA13-IID4 bound to CRP. ScFv-Fc-scFv antibodies containing scFv $\mathrm{PhOx}$ in combination with a CRP specific scFv bound both antigens revealing dual antigen specificity. None of the antibody constructs bound to the negative control antigen BSA. Constructs containing the CRP specific scFv TOB5-D4 showed some tendency for unspecific binding to PhOx-BSA but not to BSA, therefore, TOB5-D4 may not have properly folded at the carboxyterminal position of the Fc moiety in comparison to the other scFvs. Fc-scFv HuM195 and scFv-Fc-scFv LA13-IIE3 x HuM195 bound specifically to CD33 ${ }^{+}$HL60 cells but not CD33- Karpas 299 cells in flow cytometry (data not shown), but with less efficiency as previously shown with the HuM195 based scFv-Fc antibody [28]. The BW431/26 based construct were not tested for CEA binding due to very low concentration after purification. 
Figure 4. Homodimer formation of $\mathrm{scFv}-\mathrm{Fc}, \mathrm{Fc}-\mathrm{scFv}$ and $\mathrm{scFv}-\mathrm{Fc}-\mathrm{scFv}$ antibodies. (A) ScFv-Fc LA13-IIE3, (B) Fc-scFv LA13-IIE3 and (C) scFv-Fc-scFv antibodies LA13-IIE3 × LA13-IIE3, (D) LA13-IIE3 × TOB4-B11, and (E) LA13-IIE3 × TOB5-D4 were analyzed by analytical SEC performed with a Superdex 200 20/300 GL column and Äkta purifier system using PBS as running buffer. Calibration (grey line with orange squares) was undertaken with the following molecular weight standards: blue dextran, 2,000 kDa; beta amylase, $200 \mathrm{kDa}$; alcohol dehydrogenase, $150 \mathrm{kDa}$; albumin, $66 \mathrm{kDa}$; carbonic anhydrase, $29 \mathrm{kDa}$; cytochrome C, $12.4 \mathrm{kDa}$.
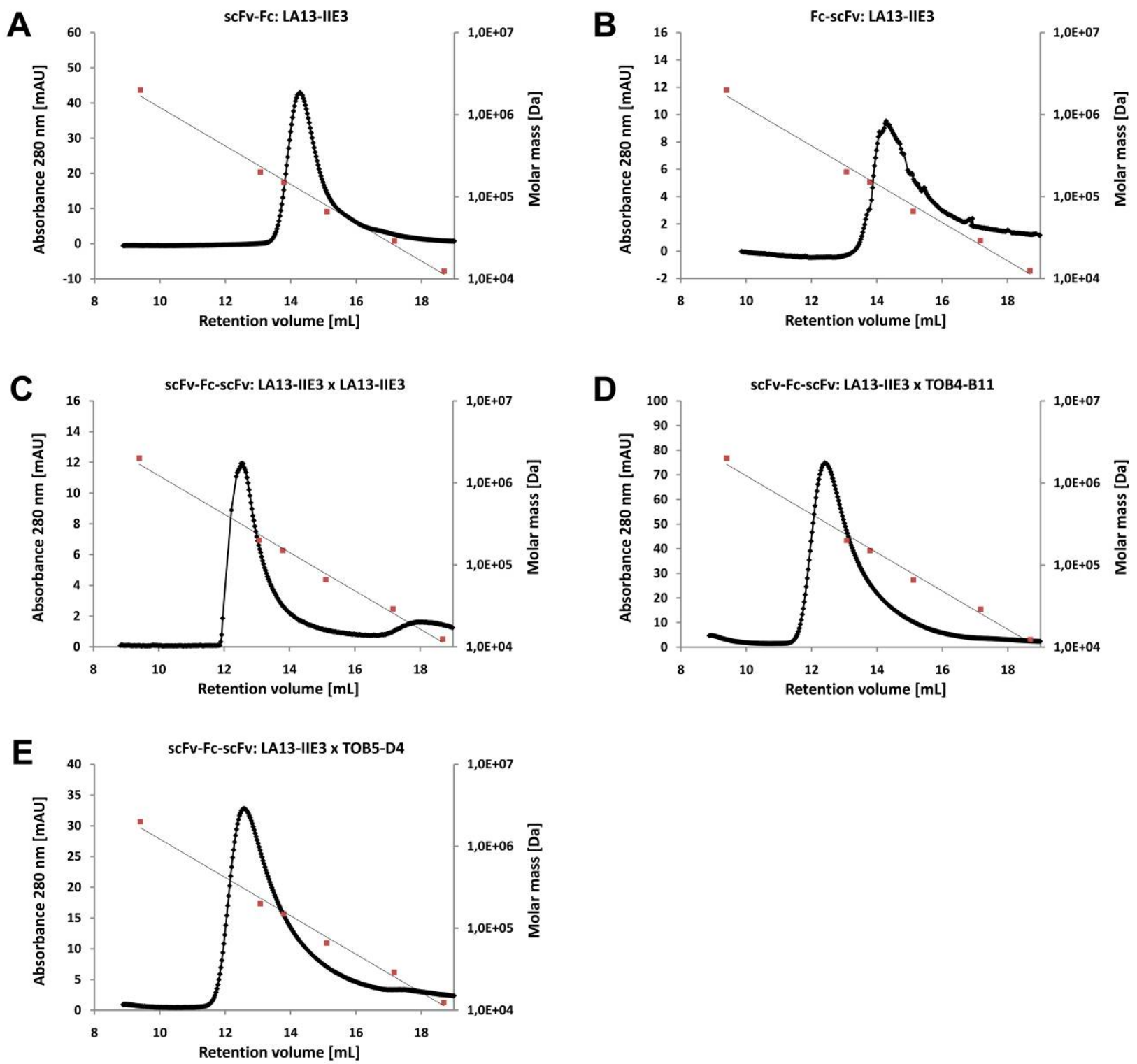

\subsection{Avidity Effects of Tetravalent Antigen Binding by scFv-Fc-scFv Antibodies}

Different antibody formats containing only CRP specific $\mathrm{scFv}$ domains including monovalent scFv LA13-IIE3, bivalent scFv-Fc and Fc-scFv LA13-IIE3 as well as tetravalent scFv-Fc-scFv LA13-IIE3 × LA13-IIE3, LA13-IIE3 × TOB4-B11 and LA13-IIE3 × TOB5-D4 were compared regarding their antigen binding in ELISA (Figure 6, Table 2). The scFv bound CRP only at relatively 
high concentrations of more than $10 \mathrm{nM}$. The bivalent Fc-scFv containing the scFv LA13-IIE3 domains at the carboxyterminus of the Fc bound 20-fold more efficiently to CRP than the scFv. In contrast, the scFv-Fc antibody with same scFv domain at the aminoterminus of the Fc bound to CRP 2.5-fold more efficiently than the Fc-scFv antibody which has a 50-fold higher antigen binding than that of the monovalent scFv fragment. Presumably, carboxyterminal fusion of the $\mathrm{scFv}$ in $\mathrm{Fc}-\mathrm{scFv}$ reduces the accessibility of its antigen binding domain in comparison to the scFv-Fc format. The scFvFc-scFv antibodies LA13-IIE3 $\times$ LA13-IIE3 and LA13-IIE3 $\times$ TOB4-B11 had a very low 50\% effective concentration $\left(\mathrm{EC}_{50}\right)$ for CRP binding of 40-50 pM which is 400-500 fold lower than that of the monovalent scFv LA13-IIE3 and about 10-fold lower than that of the bivalent scFv-Fc LA13-IIE3. In contrast, scFv-Fc-scFv LA13-IIE3 $\times$ TOB4-B11 did not bind more effectively than the scFv-Fc LA13-IIE3, which demonstrates that not all scFv combinations result in higher antigen binding.

Figure 5. Dual antigen specificity assay. Antigen-ELISA was performed with the antigen CRP or PhOx-BSA, respectively, and BSA used as negative control. A total of $100 \mathrm{ng} / \mathrm{well}$ scFv-Fc, Fc-scFv and scFv-Fc-scFv was used and detected with an anti-human IgG (Fc specific) secondary antibody conjugate. Secondary antibody only was used as negative control for this assay.

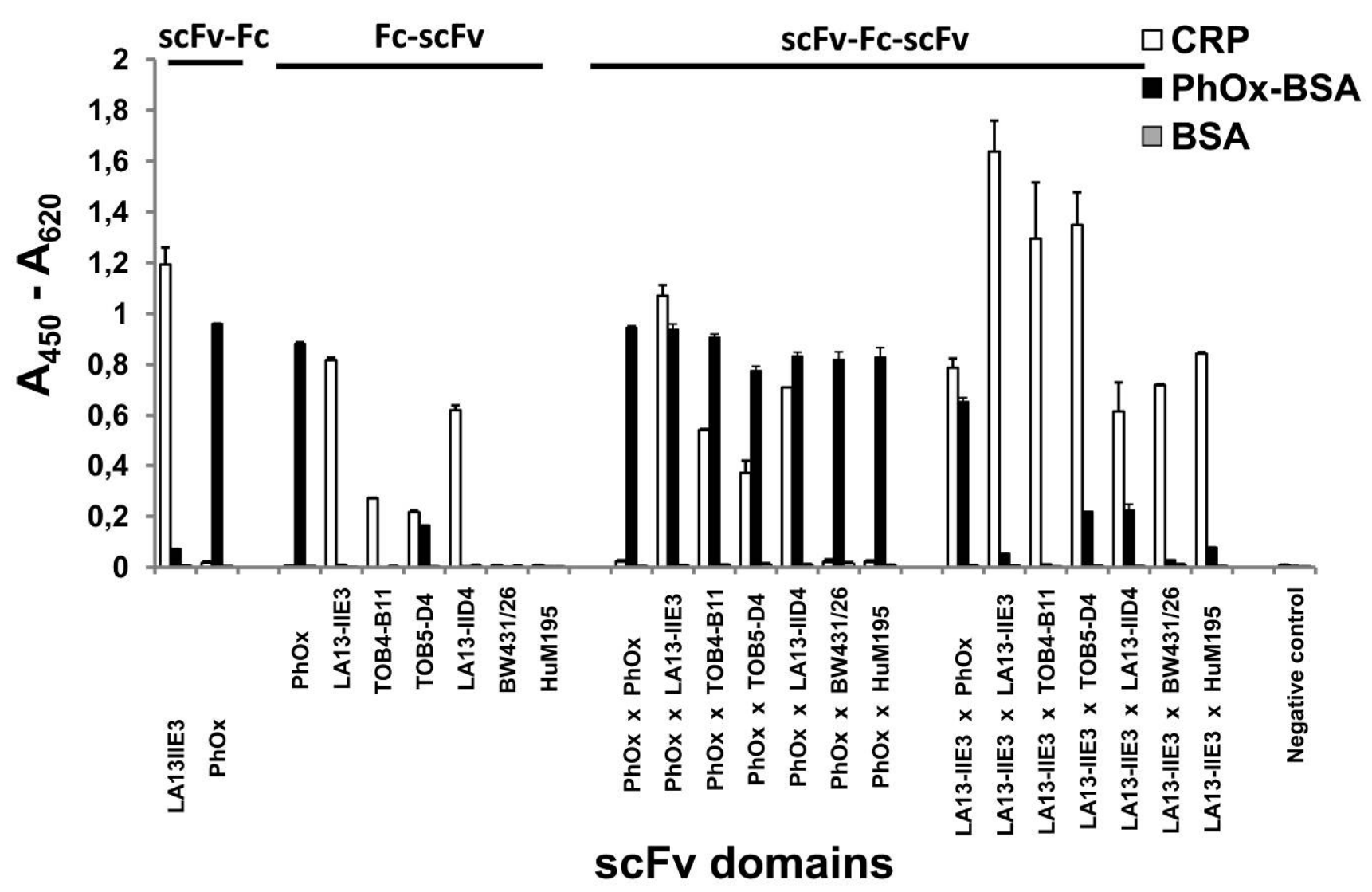

The bivalent scFv-Fc LA13-IIE3 achieved the highest overall absorbance in antigen ELISA of all constructs. An obvious explanation for this phenomenon would be the better accessibility of its free Fc carboxyterminus to secondary antibody conjugate used for detection. Unspecific binding to PhOx-BSA only occurred at concentrations or more than $3 \mathrm{nM}$ with the construct scFv-Fc-scFv LA13-IIE3 $\times$ TOB5-D4. 
Figure 6. Avidity effects. (A) Monovalent scFv (LA13-IIE3, dotted line), bivalent scFv-Fc and Fc-scFv (LA13-IIE3, dashed lines), as well as tetravalent scFv-Fc-scFv antibodies (LA13-IIE3 × LA13-IIE3, LA13-IIE3 × TOB4-B1, and LA13-IIE3 × TOB5-D4; solid lines) were incubated with serial dilutions in CRP coated ELISA wells. (B) PhOx-BSA was used as negative control antigen. $(\mathbf{C})$ In order to determine the $50 \%$ effective concentration $\left(\mathrm{EC}_{50}\right)$ of CRP binding, absorbances were normalized to the maximum value measure for each construct. Detection of the scFv was done with the mouse $\alpha$-myc-tag monoclonal antibody (Myc1-9E10) and a mouse IgG specific secondary antibody conjugate whereas scFv-Fc, $\mathrm{Fc}-\mathrm{scFv}$ and the scFv-Fc-scFv antibodies were detected with an anti-human IgG (Fc-specific) antibody conjugate. The $\mathrm{scFv}$ domains and their position regarding the $\mathrm{Fc}$ moiety are indicated for each construct.

A

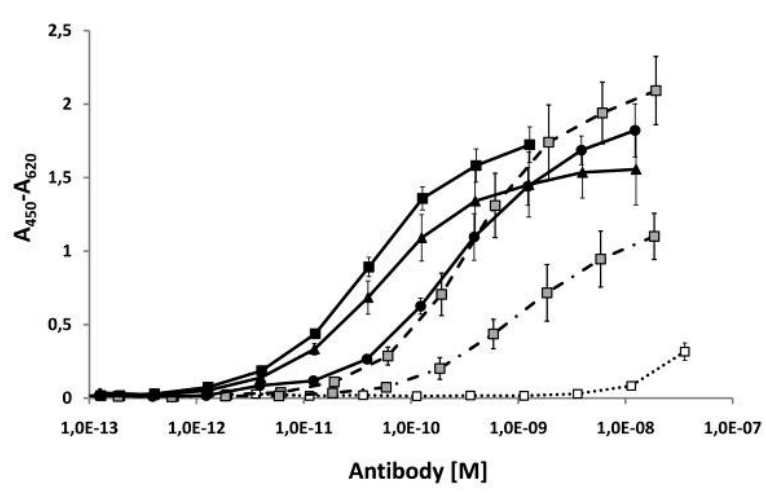

C

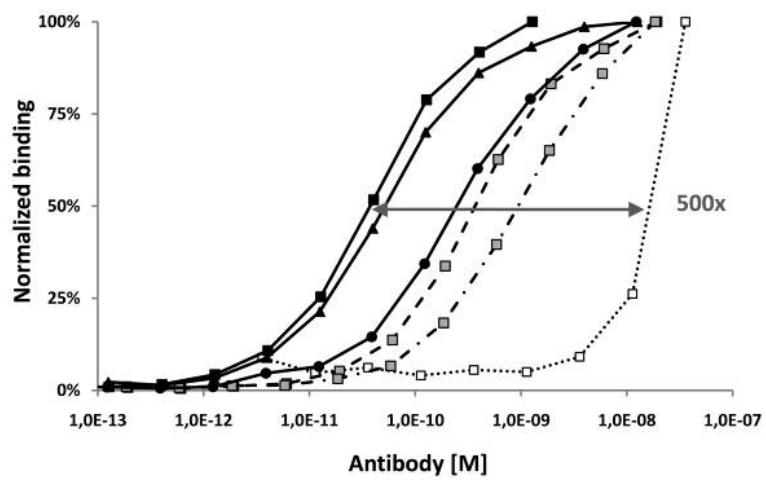

B

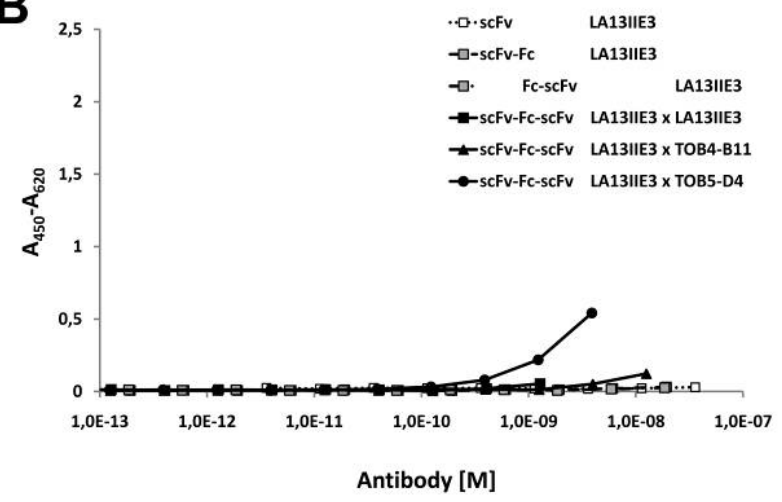

Table 2. Antigen binding of CRP-specific mono-, bi- and tetravalent antibody constructs.

\begin{tabular}{|l|l|l|l|l|l|}
\hline Antibody construct & scFv- & Fc & -scFv & EC $_{\mathbf{5 0}}[\mathbf{M}] *$ & $\begin{array}{l}\text { Increase of CRP } \\
\text { binding (fold) } * *\end{array}$ \\
\hline scFv $* * *$ & LA13-IIE3 & - & - & $2 \times 10^{-8}$ & 1 \\
\hline scFv-Fc & LA13-IIE3 & + & - & $4 \times 10^{-10}$ & 50 \\
\hline Fc-scFv & - & + & LA13-IIE3 & $1 \times 10^{-9}$ & 20 \\
\hline scFv-Fc-scFv & LA13-IIE3 & + & LA13-IIE3 & $4 \times 10^{-11}$ & 500 \\
\hline scFv-Fc-scFv & LA13-IIE3 & + & TOB4-B11 & $5 \times 10^{-11}$ & 400 \\
\hline scFv-Fc-scFv & LA13-IIE3 & + & TOB5-D4 & $4 \times 10^{-10}$ & 50 \\
\hline
\end{tabular}

* determined by antigen ELISA; $* *$ with respect to $\mathrm{EC}_{50}$ of $\mathrm{scFv} ; * * *$ different detection system, saturation was not reached at the highest tested concentration. 


\subsection{Tetravalent $s c F v-F c$-scFv Antibodies Have Slower off-Rates Compared to Bivalent and}

\section{Monovalent Antibody Formats}

In order to eliminate possible interference of the detection system in ELISA, binding was also studied in a label-free antigen binding assay using surface plasmon resonance (SPR). Binding kinetics of CRP-specific bivalent scFv-Fc and different tetravalent $\mathrm{scFv}-\mathrm{Fc}-\mathrm{scFv}$ antibodies (=analytes) to pentameric CRP coupled as ligand to a CM5 sensor chip were measured. Since interaction of multivalent analytes to a multivalent ligand is too complex for standard models, we used the 1:1 Langmuir model only to approximate the apparent dissociation constant $\left(\mathrm{K}_{\mathrm{D}}\right)$ and to allow comparison of monovalent scFv, bivalent scFv-Fc, and tetravalent scFv-Fc-scFv antibodies (Table 3). Generally, all CRP specific tetravalent scFv-Fc-scFv antibodies had slower off-rates than the bivalent scFv-Fc and monovalent scFv LA13-IIE3. The scFv-Fc-scFv LA13-IIE3 $\times$ LA13-IIE3 had the lowest apparent $\mathrm{K}_{\mathrm{D}}$ of $72 \mathrm{pM}$ which is 140-fold lower in comparison to the monovalent scFv fragment and 34-fold lower in comparison to the bivalent $s c F v-F c$. The apparent $K_{D}$ values of the other two tetravalent constructs still were in the subnanomolar range. However, the high $\mathrm{Chi}^{2}$ values of the 1:1 Langmuir curve fitting of all multivalent antibodies reflect the low quality of this model to approximate the real binding kinetics. We also used the bivalent analyte model for $\mathrm{scFv}-\mathrm{Fc}$ and $\mathrm{scFv}-\mathrm{Fc}-\mathrm{scFv}$ antibodies which generally resulted in a better fitting and lower $\mathrm{Chi}^{2}$ values (Table 4). The tetravalent scFv-Fc-scFv antibodies again had lower off-rates than the bivalent scFv-Fc.

Table 3. Binding kinetics measured by SPR and analyzed using the 1:1 Langmuir model.

\begin{tabular}{|c|c|c|c|c|c|c|c|c|c|}
\hline \multicolumn{2}{|c|}{ Antibody construct } & $\mathbf{k}_{\text {on }}$ & $\mathbf{k}_{\text {off }}$ & $\mathbf{R}_{\max }$ & $\mathbf{C h i}^{2}$ & \multicolumn{3}{|c|}{$\mathbf{K}_{\mathbf{D}}$ * } \\
\hline scFv- & Fc & $-\mathbf{s c F v}$ & {$[\mathbf{1} / \mathbf{M s}]$} & {$[\mathbf{1} / \mathbf{s}]$} & {$[\mathbf{R U}]$} & & {$[\mathbf{M}]$} & $\begin{array}{c}\text { Ratio to } \\
\mathbf{s c F v}\end{array}$ & $\begin{array}{c}\text { Ratio to } \\
\text { scFv-Fc }\end{array}$ \\
\hline LA13-IIE3 $* *$ & - & - & $1.6 \times 10^{5}$ & $1.6 \times 10^{-3}$ & 160 & 16,6 & $1.0 \times 10^{-8}$ & 1.0 & - \\
\hline LA13-IIE3 & + & - & $2.1 \times 10^{6}$ & $5.1 \times 10^{-3}$ & 154 & 65,1 & $2.5 \times 10^{-9}$ & 4.2 & 1.0 \\
\hline LA13-IIE3 & + & LA13-IIE3 & $4.3 \times 10^{6}$ & $3.1 \times 10^{-4}$ & 216 & 65,4 & $7.2 \times 10^{-11}$ & 141.9 & 34.1 \\
\hline LA13-IIE3 & + & TOB4-B11 & $1.2 \times 10^{6}$ & $6.3 \times 10^{-4}$ & 131 & 116,0 & $5.2 \times 10^{-10}$ & 19.8 & 4.8 \\
\hline LA13-IIE3 & + & TOB5-D4 & $1.6 \times 10^{6}$ & $7.8 \times 10^{-4}$ & 157 & 131 & $5.0 \times 10^{-10}$ & 20.8 & 5.0 \\
\hline
\end{tabular}

${ }^{*}$ For bi- and tetravalent only apparent $\mathrm{K}_{\mathrm{D}}$; ** Data from [32].

Table 4. Binding kinetics measured by SPR and analyzed using the bivalent analyte model.

\begin{tabular}{|c|c|c|c|c|c|c|}
\hline \multicolumn{2}{|c|}{ Antibody construct } & $\mathbf{k}_{\text {on1 }}$ & $\mathbf{k}_{\text {off1 }}$ & $\mathbf{R}_{\max }$ & Chi $^{\mathbf{2}}$ \\
\hline scFv- & Fc & $-\mathbf{s c F v}$ & {$[\mathbf{1} / \mathbf{M s}]$} & {$[\mathbf{1} / \mathbf{s}]$} & {$[\mathbf{R U}]$} & \\
\hline LA13-IIE3 & + & - & $9.5 \times 10^{5}$ & $6.5 \times 10^{-3}$ & 178 & 6.93 \\
\hline LA13-IIE3 & + & LA13-IIE3 & $1.2 \times 10^{6}$ & $2.7 \times 10^{-3}$ & 378 & 12.3 \\
\hline LA13-IIE3 & + & TOB4-B11 & $6.3 \times 10^{5}$ & $1.2 \times 10^{-3}$ & 161 & 22.6 \\
\hline LA13-IIE3 & + & TOB5-D4 & $8.0 \times 10^{5}$ & $1.4 \times 10^{-3}$ & 191 & 36.7 \\
\hline
\end{tabular}




\section{Experimental Section}

\subsection{Single Chain (sc)Fv Antibody Gene Fragments}

The scFv PhOx (PhOx-Yol) is specific for the hapten 2-phenyloxazoline -5-one (phOx) and is described elsewhere [33]. CRP specific scFv antibody fragments LA13-IIE3 and LA13-IID4 were obtained from a semisynthetic scFv antibody gene library by phage display and were described elsewhere [32]. The scFv antibody fragments TOB4-B11 and TOB5-D4 were isolated against CRP from naïve human antibody gene library HAL7 [1] as described below. The scFvs BW431/26 and HuM195 were previously generated from humanized antibodies [27,28].

\subsection{Selection of scFvs against Human CRP by Phage Display}

CRP specific scFv antibody gene fragments TOB4-B11 and TOB5-D4 were isolated from the naïve human antibody gene library HAL7 [1] by panning in polystyrole microtiter stripes as described [34]. Briefly, Maxisorp microtiter stripe wells (Nunc, Langenselbold, Germany) were coated with $100 \mu \mathrm{L}$ per well of $1 \mu \mathrm{g} / \mathrm{mL}$ human recombinant CRP (BiosPacific, Emeryville, USA) in phosphate buffered saline (PBS: pH 7.4, 10× stock solution contains $1.37 \mathrm{M} \mathrm{NaCl}, 26 \mathrm{mM} \mathrm{KCl}, 80 \mathrm{mM} \mathrm{Na} 2 \mathrm{HPO}_{4}, 15 \mathrm{mM}$ $\mathrm{KH}_{2} \mathrm{PO}_{4}$ ) overnight at $4{ }^{\circ} \mathrm{C}$. Antigen coated wells were blocked with MPBST consisting of $2 \%(\mathrm{w} / \mathrm{v})$ skim milk powder (Roth, Karlsruhe, Germany) in PBST (PBS with 0.05\% [v/v] Tween-20 [Serva, Heidelberg, Germany]) for $1 \mathrm{~h}$ at room temperature (RT), followed by three washing steps with PBST. A total of $10^{11}$ to $10^{12}$ colony forming units (cfu) phage of the antibody gene libraries were pre-incubated in MPBST blocked wells for $1 \mathrm{~h}$ at RT to pre-adsorb unspecific binding phage. Supernatant was transferred into antigen-coated wells and incubated for $2 \mathrm{~h}$ at RT. Non-bound antibody phage were removed by ten stringent washing steps with PBST using the ELISA washer Columbus Pro (TECAN, Crailsheim, Germany). In the next panning rounds the numbers of washing steps were increased to 20 and 30, respectively. Bound phage were eluted with $200 \mu \mathrm{L} / \mathrm{well}$ of $10 \mu \mathrm{g} / \mathrm{mL}$ trypsin solution for $30 \mathrm{~min}$ at $37{ }^{\circ} \mathrm{C}$ and then re-infected into Escherichia coli XL1-Blue MRF' and produced as described [35]. After three panning rounds, $\mathrm{scFv}$ antibody clones were isolated and screened by soluble production in E. coli and antigen ELISA as described $[1,36]$.

\subsection{ScFv Production and Purification}

ScFv LA13-IIE3 was produced in E. coli XL1-Blue MRF' using the scFv expression vector pOPE101 [37] and purified by affinity chromatography using immobilized metal affinity chromatography (IMAC) using $0.5 \mathrm{~mL}$ Chelating Sepharose Fast Flow (GE Healthcare, Munich, Germany) as previously described [38].

\subsection{Construction of pCMV2.2- and pCMV5.2-hIgGIFc-XP Vectors and the $s c F v-F c, F c-s c F v$ and $s c F v-F c-s c F v$ Antibody Constructs}

The mammalian expression vectors pCMV2.2-hIgG1Fc-XP and pCMV4.2-hIgG1Fc-XP are derivatives of pCMV-hIgG1Fc-XP [6] with a modified 5' end of the Fc gene fragment. The 5' lysine codon of the Fc gene fragment is substituted by a serine codon in order to obtain a BamHI fusion 
cloning site in pCMV4.2-hIgG1Fc-XP. The BamHI site and the following downstream $X b a$ I site were used for cloning a gene fragment generated by a fill-in reaction using the desoxyoligonucleotides TS_pCMV52_BsmB1_f (5'-AACAGGATCC-GGTGGCGGAACTAGTGG-CATGTGAGACGTAACTAAGAAG-CGTCTC-TGGCCTGAGTGCG-TCTAGAACAA 3'; recognition sites of the restriction enzymes $\underline{B a m H \mathrm{I}}, \underline{\underline{B s m B I}}$ (NcoI' overhang), $\underline{\underline{B s m B I}}($ 'NotI overhang), and $\underline{X b a \mathrm{I}}$ are indicated) and TS_pCMV52_BsmB1_r (5' TTGT-TCTAGA-CGCACTCAG 3'; recognition site of the restriction enzyme $\underline{X b a \mathrm{I}}$ is indicated) and the Phusion ${ }^{\mathrm{TM}}$ DNA polymerase (New England Biolabs, NEB, Frankfurt, Germany). High quality plasmid preparation for transfection was done using the NucleoBond Xtra Midi Kit according to the manufacturer's description (Machery Nagel, Düren, Germany).

\subsection{Antigens}

Human CRP for ELISA was obtained from Applichem (Darmstadt, Germany). PhOx-BSA was produced by incubating $10 \mathrm{mg} / \mathrm{mL}$ bovine serum albumin (BSA; Sigma-Aldrich, Munich, Germany) and $0.67 \mathrm{mg} / \mathrm{mL}$ 4-ethoxymethylene-2-phenyl-2-oxazoline-5-on (PhOx; Sigma) corresponding to a molar ratio of $1: 20$ in $100 \mathrm{mM} \mathrm{NaHCO} 3(\mathrm{pH} \mathrm{8.5)}$ for $2-4 \mathrm{~h}$ at RT. Free hapten was removed by dialysis against PBS at $4{ }^{\circ} \mathrm{C}$.

\subsection{Cell Culture}

The human embryonic kidney cell line HEK293T/17 was obtained from American type culture collection (ATCC, LGC Standards GmbH, Wesel, Germany: ATCC-No. CRL-11268) and cultured in Dulbecco's modified Eagle's medium (DMEM, with high glucose $(4.5 \mathrm{~g} / \mathrm{L})$ and $2 \mathrm{mM}$ L-glutamine supplemented with $8 \%(\mathrm{v} / \mathrm{v})$ fetal calf serum (FCS) and with $100 \mathrm{U} / \mathrm{mL}$ penicillin and $0.1 \mathrm{mg} / \mathrm{mL}$ streptomycin (PAA, Parching, Germany). Cells were detached using trypsin $(5.0 \mathrm{mg} / \mathrm{mL}) / \mathrm{EDTA}$ (Titriplex III, $2.2 \mathrm{mg} / \mathrm{mL}$ ) (PAA).

\subsection{Transient Transfection and Production in HEK293T Cells}

Transient production in adherent HEK293T was done as previously described [6]. Briefly, one day before transfection 4-6 $610^{6}$ HEK293T cells in $12.5 \mathrm{~mL}$ culture medium were seeded into $10 \mathrm{~cm}$ plates (Greiner Bio-one, Frickenhausen, Germany) and incubated overnight. Next day, plates were about $70-80 \%$ confluent. Transfection was performed with $80 \mu \mathrm{g}$ polyethyleneimine (PEI, Polysciences, Warrington, PA) and $10 \mu \mathrm{g}$ plasmid-DNA both separately prediluted in $600 \mu \mathrm{L}$ DMEM. DNA and PEI solutions were mixed and incubated for 15-30 min at RT and then distributed over the cells. After $24 \mathrm{~h}$ medium was completely replaced by DMEM supplemented with 4\% (w/v) IgG stripped FCS (PAA) to minimize co-purification of bovine IgG by protein A/G affinity chromatography. The medium was harvested and exchanged every day for up to two weeks. 


\subsection{Quantification of Antibodies by IgG/Fc Capture ELISA}

The antibodies in the production supernatants were quantified by $\operatorname{IgG/Fc}$ capture ELISA as described [39]. Briefly, a total of $100 \mu \mathrm{L} /$ well goat-anti-human immunoglobulin (polyvalent) capture antibody (Sigma, Cat.-No. I1761; diluted $200 \mathrm{ng} / \mathrm{mL}$ in PBS) was coated in 96-well Maxisorp microtiter plates (Nunc) for $1 \mathrm{~h}$ at $37^{\circ} \mathrm{C}$. After blocking with $30 \%(\mathrm{v} / \mathrm{v}) \mathrm{FCS}$ for $1 \mathrm{~h}$ at $37^{\circ} \mathrm{C}$, the wells were washed 3 times with PBST (PBS with $0.05 \%$ [v/v] tween-20, Sigma) using an Columbus ELISA washer (TECAN, Crailsheim, Germany). Several dilutions of each sample and a half dilution series of the human IgG protein standard (N-protein SL, Dade Behring, now Siemens Healthcare Diagnostics, Eschborn, Germany; starting concentration $50 \mathrm{ng} / \mathrm{mL})$ were prepared in PBST with $1 \%(\mathrm{v} / \mathrm{v})$ FCS and $100 \mu \mathrm{L} /$ well incubated for $1 \mathrm{~h}$ at $37{ }^{\circ} \mathrm{C}$. After washing, a total of $100 \mu \mathrm{L} /$ well of $20 \mathrm{ng} / \mathrm{mL}$ goat-antihuman-IgG (Fc-specific) antibody horseradish peroxidase (HRP) conjugate (Sigma, Cat.-No. A0170) was incubated for $1 \mathrm{~h}$ at $37{ }^{\circ} \mathrm{C}$. After washing, the color reaction was initiated with $100 \mu \mathrm{L} /$ well 3,3',5,5'-tetramethylbenzidine (TMB) substrate solution (mix freshly 20 volumes TMB solution A consisting of $30 \mathrm{mM}$ potassium citrate, $0.5 \mathrm{mM}$ citric acid, $\mathrm{pH} 4.1$ with 0.5 volumes of TMB solution $\mathrm{B}$ consisting of $10 \mathrm{mM}$ TMB solved in $10 \%[\mathrm{v} / \mathrm{v}]$ acetone, $89 \%[\mathrm{v} / \mathrm{v}]$ ethanol, $0.3 \%[\mathrm{v} / \mathrm{v}] \mathrm{H}_{2} \mathrm{O}_{2}$ ) and stopped by addition of $100 \mu \mathrm{L} /$ well of $0.5 \mathrm{~N} \mathrm{H}_{2} \mathrm{SO}_{4}$. The absorbance was measured at $450 \mathrm{~nm}$ against reference wavelength of $620 \mathrm{~nm}\left(\mathrm{~A}_{450}-\mathrm{A}_{620}\right)$ using the Sunrise ELISA reader (TECAN).

\subsection{Protein Purification with Protein A Magnetic Beads and by Protein A Filtration}

Preliminary tests were done by purifying the scFv-Fc, Fc-scFv and scFv-Fc-scFv antibodies from supernatants of transfected HEK293T cells using protein A magnetic beads (New England Biolabs, NEB, Frankfurt, Germany) according to the manufacturer's description. Briefly, a total of $5 \mu \mathrm{L}$ protein A magnetic beads were used to bind $1 \mu \mathrm{g}$ of the scFv, Fc-scFv or scFv-Fc-scFv antibodies in binding buffer (20 mM sodium phosphate, $\mathrm{pH}$ 7.0) using a magnetic stand. After three washing steps with binding buffer, antibodies were eluted in $50 \mu \mathrm{L} 200 \mathrm{mM}$ glycine/ $\mathrm{HCl}, \mathrm{pH} 2.5$ and neutralized with $20 \mu \mathrm{L} 1 \mathrm{M}$ Tris-HCl, pH 9.0. Purification of milligram amounts was done with Sartobind protein A filters (Sartorius, Göttingen, Germany) according to the manufacturer's protocol. Elution was performed with $100 \mathrm{mM}$ glycin/ $\mathrm{HCl}, \mathrm{pH} 2.8$. Elution fractions were neutralized with an appropriate amount of Tris-HCl, $\mathrm{pH} 9.0$ and dialyzed against PBS.

\subsection{SDS-PAGE and Silver Staining}

SDS-PAGE was performed as described [40]. Protein samples were prepared under reducing conditions with sample buffer (containing beta-mercaptoethanol) for $5 \mathrm{~min}$ at $95{ }^{\circ} \mathrm{C}$ or under non-reducing conditions (sample buffer without reducing agent) for $10 \mathrm{~min}$ at $65{ }^{\circ} \mathrm{C}$. Silverstaining was done with little modification after the method of Blum, Beier and Gross [41]. Briefly, polyacrylamide gels were fixed overnight in 50\% (v/v) methanol, 12\% (v/v) acetic acid and $0.05 \%$ (v/v) formaline (37\% formaldehyde, Roth) at RT. After three washing steps in $50 \%(\mathrm{v} / \mathrm{v})$ ethanol for each $20 \mathrm{~min}$, the gel was incubated in sodium thiosulfate solution $\left(0.02 \%\right.$ [w/v] $\left.\mathrm{Na}_{2} \mathrm{~S}_{2} \mathrm{O}_{3} \times 5 \mathrm{H}_{2} \mathrm{O}\right)$. After three washing steps in water for $20 \mathrm{~s}$, gels were incubated in freshly prepared silver solution $\left(2 \%[\mathrm{w} / \mathrm{v}] \mathrm{AgNO}_{3}\right.$ solution, $0.075 \%[\mathrm{v} / \mathrm{v}]$ formaline) for $20 \mathrm{~min}$. After two washing steps in water for 
$20 \mathrm{~s}$, gels were incubated in freshly prepared developer solution $\left(6 \%[\mathrm{w} / \mathrm{v}] \mathrm{Na}_{2} \mathrm{CO}_{3}, 0.05 \% \mu \mathrm{L}\right.$ formaline, $2 \%[\mathrm{v} / \mathrm{v}]$ of sodium thiosulfate solution) for 1 to $10 \mathrm{~min}$ until the protein bands appeared. The reaction was stopped by two washing steps in water for $2 \mathrm{~min}$ and a final incubation in stop solution $(50 \%[\mathrm{v} / \mathrm{v}]$ methanol, $12 \%[\mathrm{v} / \mathrm{v}]$ acetic acid $)$.

\subsection{Analytical Size Exclusion Chromatograpy (SEC)}

A total of 50 to $100 \mu \mathrm{g} \mathrm{scFv}-\mathrm{Fc}, \mathrm{Fc}-\mathrm{scFv}$ or scFv-Fc-scFv, respectively, were injected onto a Superdex 10/300 GL using the Äkta Purifier fast performance liquid chromatography (FPLC) system (GE Healthcare, Freiburg, Germany) with PBS, pH 7.4 at a flow rate of $0.5 \mathrm{~mL} / \mathrm{min}$.

\subsection{Antigen ELISA}

Antigen ELISAs were performed as previously described. Briefly, a total of $100 \mathrm{ng} / \mathrm{well}$ of CRP, PhOx-BSA or BSA, respectively, were coated onto Maxisorp 96-well microtiter plates (Nunc). After washing using an ELISA washer (TECAN) and blocking with 2\% M-PBST, $100 \mu \mathrm{L}$ per well of $100 \mathrm{ng} / \mathrm{mL}$ scFv-Fc, Fc-scFv and scFv-Fc-scFv antibody or serial dilutions of these antibody constructs were prepared in blocking buffer and incubated for $1 \mathrm{~h}$ at RT. After three washing steps bound scFv-Fc, Fc-scFv and scFv-Fc-scFv were detected by staining with a goat-anti-human IgG (Fc-specific) secondary antibody HRP conjugate (Sigma). The scFv LA13-IIE3 was detected with $100 \mu \mathrm{L} /$ well mouse $\alpha$-myc-tag monoclonal antibody Myc1-9E10 (1:1,000; Sigma) and polyclonal goat $\alpha$-mouse IgG (Fab-specific) antibody HRP conjugate (1:20,000; Sigma). Color reaction was performed using TMB as described above. Absorbances were measured at $450 \mathrm{~nm}$ against reference wavelength of $620 \mathrm{~nm}\left(\mathrm{~A}_{450}-\mathrm{A}_{620}\right)$ using the Sunrise ELISA reader (TECAN).

\subsection{Affinity and Kinetics Measurements}

Affinity measurements were performed by surface plasmon resonance analysis (SPR) using a CM5 chip on a Biacore $2000^{\mathrm{TM}}$ (GE Healthcare). Human CRP and control protein lysozyme were bound as ligands in different channels of the CM5 chip via amine coupling following the manufacturer's instructions. The flow rate was set to $10 \mu \mathrm{L} / \mathrm{min}$ for association and $25 \mu \mathrm{L} / \mathrm{min}$ for dissociation using $10 \mathrm{mM}$ 4-(2-hydroxyethyl)-1-piperazineethanesulfonic acid (HEPES) buffer (pH 7.4) with $0.15 \mathrm{M}$ $\mathrm{NaCl}, 3 \mathrm{mM}$ EDTA and $0.005 \%(\mathrm{v} / \mathrm{v})$ surfactant P20 $\left(25^{\circ} \mathrm{C}\right)$. Chip regeneration was done with $50 \mathrm{mM}$ $\mathrm{HCl}$. Analyte samples of scFv-Fc-LA13-IIE3 and scFv-Fc-scFv (LA13-IIE3 $\times$ LA13-IIE3, LA13-IIE3 $\times$ TOB4-B11 or LA13-IIE3 $\times$ TOB5-D4) were diluted to obtain a concentration series from 100 to $1 \mathrm{nM}$. Analysis was performed using the BIA evaluation software using the 1:1 Langmuir and bivalent analyte models.

\section{Conclusions}

The design of the vector pCMV5.2-hIgG1Fc-XP allows simple two-step cloning of single chain antibody gene fragments into the scFv-Fc-scFv antibody format which can be used to generate monospecific as well as bispecific IgG-like tetravalent antibodies. Transient mammalian production in HEK293T cells allowed yields useful for initial studies for most of the antibody constructs. However, 
we observed a strong dependency of expression from the employed $\mathrm{scFv}$ fragments particularly from those introduced at the carboxyterminus of the Fc. All scFv-Fc-scFv antibodies except those containing the $\mathrm{scFv}$ BW431/26 were produced in sufficient yields to be used in further applications. Moreover, we also demonstrated that testing several $\mathrm{scFv}$ combinations can also result in scFv-Fc-scFv antibodies which are produced in several $\mathrm{mg} / \mathrm{L}$ yields. Novel transient mammalian expression systems [6], as well as efficient stable mammalian production processes can increase the production levels of scFv-Fc-scFv antibodies [12,25]. The scFv-Fc-scFv antibodies exclusively formed disulfide-bound homodimers as previously shown by other research groups even with less tendency to form aggregates than $\mathrm{scFv}$ fragments $[12,25]$. The combination of different antigen specificities in one scFv-Fc-scFv construct resulted in all cases in dual specificity of the molecules as tested by antigen ELISA or flow cytometry. Although simultaneous binding of two different antigens was not tested in this study, the scFv-Fc-scFv antibody format seems to be less prone to mutual interference, since both scFv antibody fragments are located on the different termini of the Fc moiety. Despite the soluble and flexible ten amino acid spacer sequence which we introduced between Fc and carboxyterminal scFv, Fc-scFv antibodies generally bound less efficiently to their antigens than scFv-Fc antibodies with scFv and Fc arranged in reverse order. Antigen binding of the carboxyterminal $\mathrm{scFv}$ fragments can probably be improved by using longer linkers but it is still unlikely to completely reconstitute the binding properties of scFvs with a free aminoterminus, because the antigen binding regions of antibodies display towards a free aminoterminus in immunoglobulins. A bias regarding a free aminoterminus can also be expected for recombinant antibodies isolated by phage display because antibody fragments can only be fused to the major phage coat protein pIII in scFv-pIII orientation.

We tested the effect of antibody valency to bind multimeric antigens. The avidity effect of CRP-specific bivalent scFv-Fc and tetravalent scFv-Fc-scFv antibodies resulted in a several hundred fold improved antigen binding compared to the monovalent scFv fragment. Tetravalent scFv-Fc-scFv antibodies showed the lowest $\mathrm{EC}_{50}$ depending on the scFv combination. The scFv-FcscFv LA13-IIE3 $\times$ LA13-IIE3 and LA13-IIE3 $\times$ TOB4-B11 antibodies had EC $_{50}$ values of only 40 to $50 \mathrm{pM}$ in ELISA with a high concentration of immobilized CRP antigen. SPR studies with a low amount of immobilized CRP revealed an apparent $\mathrm{K}_{\mathrm{D}}$ of about $70 \mathrm{pM}$ for $\mathrm{scFv}-\mathrm{Fc}-\mathrm{scFv}$ LA13-IIE3 $\times$ LA13-IIE3, which indicates more efficient simultaneous binding of three or four scFv arms of this construct to a single CRP pentamer. The other two tested scFv-Fc-scFv antibodies LA13-IIE3 $\times$ TOB4-B11 and LA13-IIE3 $\times$ TOB5-D4 still bound in the subnanomolar range to CRP which is about five times more efficient than the bivalent $\mathrm{scFv}-\mathrm{Fc}$ construct. Dual epitope recognition was not further investigated in this study but bsAbs binding to two different sites on the same antigen have been demonstrated superior functions compared to their monospecific parental antibodies. A tetravalent IgG-like bsAbs recognizing two epitopes on CD2 mediated increased mitogenic effects compared to the parental monoclonal antibodies [24]. Another bsAb blocked two alternative docking sites on human deficiency virus (HIV) coreceptor CCR5 and was able to inhibit the entry of CCR5 tropic HIV strains as well as of HIV strains that were already resistant to the parental monoclonal antibodies [11]. Moreover, bispecific scFv-Fc-scFv have been shown to effectively neutralize two different cytokines [25] or to inhibit two different angiogenic pathways in vitro and in vivo [12], thus demonstrating that this bsAb format has great potential in different applications. 
Taken together, the pCMV5.2-hIgG1Fc-XP expression system allows fast and reliable construction of tetravalent IgG-like mono- and bispecific scFv-Fc-scFv antibodies and production of several milligrams for testing and application. Although still in early stage, our scFv-Fc-scFv expression system can already be linked to our previously described high throughput antibody generation pipeline [1] to allow rapid candidate testing for tetravalent IgG-like bsAbs.

\section{Acknowledgments}

We gratefully thank Stefan Dübel and Michael Hust (Technische Universität Braunschweig, Germany) for critical discussion and reading the manuscript, and providing the scFv gene fragments and antibody gene libraries. We acknowledge the financial support by EU FP6 supported coordination action funded activities "Proteome Binders" (contract 026008) and the EU FP7 collaborative projects "Affinity Proteome" (contract 222635) and "Affinomics" (contract 241481).

\section{References and Notes}

1. Hust, M.; Meyer, T.; Voedisch, B.; Rülker, T.; Thie, H.; El-Ghezal, A.; Kirsch, M.I.; Schütte, M.; Helmsing, S.; Meier, D.; et al. A human $\mathrm{scFv}$ antibody generation pipeline for proteome research. J. Biotechnol. 2011, 152, 159-170.

2. Thie, H.; Voedisch, B.; Dübel, S.; Hust, M.; Schirrmann, T. Affinity maturation by phage display. Methods Mol. Biol 2009, 525, 309-322, xv.

3. Thie, H.; Toleikis, L.; Li, J.; von Wasielewski, R.; Bastert, G.; Schirrmann, T.; Esteves, I.T.; Behrens, C.K.; Fournes, B.; Fournier, N.; et al. Rise and fall of an anti-MUC1 specific antibody. PLoS One 2011, 6, e15921.

4. Kipriyanov, S.M.; Little, M.; Kropshofer, H.; Breitling, F.; Gotter, S.; Dübel, S. Affinity enhancement of a recombinant antibody: Formation of complexes with multiple valency by a single-chain Fv fragment-core streptavidin fusion. Protein Eng. 1996, 9, $203-211$.

5. Thie, H.; Binius, S.; Schirrmann, T.; Hust, M.; Dübel, S. Multimerization domains for antibody phage display and antibody production. N. Biotechnol. 2009, 26, 314-321.

6. Schirrmann, T.; Büssow, K. Transient production of $\mathrm{scFv}-\mathrm{Fc}$ fusion proteins in mammalian cells. In Antibody Engineering; Kontermann, R., Dübel, S., Eds.; Springer Berlin Heidelberg: Berlin, Germany, 2010; pp. 387-398.

7. Schirrmann, T.; Menzel, C.; Hust, M.; Prilop, J.; Jostock, T.; Dübel, S. Oligomeric forms of single chain immunoglobulin (scIgG). MAbs 2010, 2, 73-76.

8. McCall, A.M.; Adams, G.P.; Amoroso, A.R.; Nielsen, U.B.; Zhang, L.; Horak, E.; Simmons, H.; Schier, R.; Marks, J.D.; Weiner, L.M. Isolation and characterization of an anti-CD16 single-chain $\mathrm{Fv}$ fragment and construction of an anti-HER2/neu/anti-CD16 bispecific scFv that triggers CD16-dependent tumor cytolysis. Mol. Immunol. 1999, 36, 433-445.

9. Hammond, S.A.; Lutterbuese, R.; Roff, S.; Lutterbuese, P.; Schlereth, B.; Bruckheimer, E.; Kinch, M.S.; Coats, S.; Baeuerle, P.A.; Kufer, P.; et al. Selective targeting and potent control of tumor growth using an EphA2/CD3-bispecific single-chain antibody construct. Cancer Res. 2007, 67, 3927-3935. 
10. Mølhøj, M.; Crommer, S.; Brischwein, K.; Rau, D.; Sriskandarajah, M.; Hoffmann, P.; Kufer, P.; Hofmeister, R.; Baeuerle, P.A. CD19-/CD3-bispecific antibody of the BiTE class is far superior to tandem diabody with respect to redirected tumor cell lysis. Mol. Immunol. 2007, 44, 1935-1943.

11. Schanzer, J.; Jekle, A.; Nezu, J.; Lochner, A.; Croasdale, R.; Dioszegi, M.; Zhang, J.; Hoffmann, E.; Dormeyer, W.; Stracke, J.; et al. Development of tetravalent, bispecific CCR5 antibodies with antiviral activity against CCR5 monoclonal antibody-resistant HIV-1 strains. Antimicrob. Agents Chemother. 2011, 55, 2369-2378.

12. Mabry, R.; Gilbertson, D.G.; Frank, A.; Vu, T.; Ardourel, D.; Ostrander, C.; Stevens, B.; Julien, S.; Franke, S.; Meengs, B.; et al. A dual-targeting PDGFRbeta/VEGF-A molecule assembled from stable antibody fragments demonstrates anti-angiogenic activity in vitro and in vivo. MAbs 2010, 2, 20-34.

13. Cao, Y.; Lam, L. Bispecific antibody conjugates in therapeutics. Adv. Drug Deliv. Rev. 2003, 55, 171-197.

14. Müller, D.; Kontermann, R.E. Bispecific antibodies for cancer immunotherapy: Current perspectives. BioDrugs 2010, 24, 89-98.

15. Linke, R.; Klein, A.; Seimetz, D. Catumaxomab. MAbs 2010, 2, 129-136.

16. Bargou, R.; Leo, E.; Zugmaier, G.; Klinger, M.; Goebeler, M.; Knop, S.; Noppeney, R.; Viardot, A.; Hess, G.; Schuler, M.; et al. Tumor regression in cancer patients by very low doses of a T cellengaging antibody. Science 2008, 321, 974-977.

17. Schaefer, W.; Regula, J.T.; Bähner, M.; Schanzer, J.; Croasdale, R.; Dürr, H.; Gassner, C.; Georges, G.; Kettenberger, H.; Imhof-Jung, S.; et al. Immunoglobulin domain crossover as a generic approach for the production of bispecific IgG antibodies. Proc. Natl. Acad. Sci. USA 2011, 108, 11187-11192.

18. Muda, M.; Gross, A.W.; Dawson, J.P.; He, C.; Kurosawa, E.; Schweickhardt, R.; Dugas, M.; Soloviev, M.; Bernhardt, A.; Fischer, D.; et al. Therapeutic assessment of SEED: A new engineered antibody platform designed to generate mono- and bispecific antibodies. Protein Eng. Des. Sel. 2011, 24, 447-454.

19. Asano, R.; Watanabe, Y.; Kawaguchi, H.; Fukazawa, H.; Nakanishi, T.; Umetsu, M.; Hayashi, H.; Katayose, Y.; Unno, M.; Kudo, T.; et al. Highly effective recombinant format of a humanized IgG-like bispecific antibody for cancer immunotherapy with retargeting of lymphocytes to tumor cells. J. Biol. Chem. 2007, 282, 27659-27665.

20. Wu, C.; Ying, H.; Grinnell, C.; Bryant, S.; Miller, R.; Clabbers, A.; Bose, S.; McCarthy, D.; Zhu, R.-R.; Santora, L.; et al. Simultaneous targeting of multiple disease mediators by a dual-variable-domain immunoglobulin. Nat. Biotechnol. 2007, 25, 1290-1297.

21. Michaelson, J.S.; Demarest, S.J.; Miller, B.; Amatucci, A.; Snyder, W.B.; Wu, X.; Huang, F.; Phan, S.; Gao, S.; Doern, A.; et al. Anti-tumor activity of stability-engineered IgG-like bispecific antibodies targeting TRAIL-R2 and LTbetaR. MAbs 2009, 1, 128-141.

22. Dong, J.; Sereno, A.; Aivazian, D.; Langley, E.; Miller, B.R.; Snyder, W.B.; Chan, E.; Cantele, M.; Morena, R.; Joseph, I.B.J.K.; et al. A stable IgG-like bispecific antibody targeting the epidermal growth factor receptor and the type I insulin-like growth factor receptor demonstrates superior anti-tumor activity. MAbs 2011, 3, 273-288. 
23. Alt, M.; Müller, R.; Kontermann, R.E. Novel tetravalent and bispecific IgG-like antibody molecules combining single-chain diabodies with the immunoglobulin gamma1 Fc or $\mathrm{CH} 3$ region. FEBS Lett. 1999, 454, 90-94.

24. Connelly, R.J.; Hayden, M.S.; Scholler, J.K.; Tsu, T.T.; Dupont, B.; Ledbetter, J.A.; Kanner, S.B. Mitogenic properties of a bispecific single-chain Fv-Ig fusion generated from CD2-specific mAb to distinct epitopes. Int. Immunol. 1998, 10, 1863-1872.

25. Mabry, R.; Lewis, K.E.; Moore, M.; McKernan, P.A.; Bukowski, T.R.; Bontadelli, K.; Brender, T.; Okada, S.; Lum, K.; West, J.; et al. Engineering of stable bispecific antibodies targeting IL-17A and IL-23. Protein Eng. Des. Sel. 2010, 23, 115-127.

26. Jendreyko, N.; Popkov, M.; Beerli, R.R.; Chung, J.; McGavern, D.B.; Rader, C.; Barbas, C.F., 3rd. Intradiabodies, bispecific, tetravalent antibodies for the simultaneous functional knockout of two cell surface receptors. J. Biol. Chem. 2003, 278, 47812-47819.

27. Schirrmann, T.; Pecher, G. Human natural killer cell line modified with a chimeric immunoglobulin T-cell receptor gene leads to tumor growth inhibition in vivo. Cancer Gene Ther. 2002, 9, 390-398.

28. Schirrmann, T.; Pecher, G. Specific targeting of CD33(+) leukemia cells by a natural killer cell line modified with a chimeric receptor. Leuk. Res. 2005, 29, 301-306.

29. Jostock, T.; Vanhove, M.; Brepoels, E.; Van Gool, R.; Daukandt, M.; Wehnert, A.; Van Hegelsom, R.; Dransfield, D.; Sexton, D.; Devlin, M.; et al. Rapid generation of functional human IgG antibodies derived from Fab-on-phage display libraries. J. Immunol. Methods 2004, 289, 65-80.

30. Li, J.; Menzel, C.; Meier, D.; Zhang, C.; Dübel, S.; Jostock, T. A comparative study of different vector designs for the mammalian expression of recombinant IgG antibodies. J. Immunol. Methods 2007, 318, 113-124.

31. Goldsmith, M.E.; Konigsberg, W.H. Adsorption protein of the bacteriophage fd: Isolation, molecular properties, and location in the virus. Biochemistry 1977, 16, 2686-2694.

32. Al-Halabi, L.; Balck, A.; Michalzik, M.; Fröde, D.; Büttgenbach, S.; Hust, M.; Schirrmann, T.; Dübel, S. Recombinant antibody fragments allow repeated measurements of C-reactive protein with a quartz crystal microbalance immunosensor. J. Biotechnol. 2012, submitted.

33. Marks, J.D.; Griffiths, A.D.; Malmqvist, M.; Clackson, T.P.; Bye, J.M.; Winter, G. By-passing immunization: building high affinity human antibodies by chain shuffling. Biotechnology (N.Y.) 1992, 10, 779-783.

34. Hust, M.; Toleikis, L.; Dübel, S. Antibody phage display. Handbook of therapeutic antibodies. In Handbook of Therapeutic Antibodies; Wiley-VCH: Weinheim, Germany, 2007; Volume 1, pp. 45-68.

35. Hust, M.; Dübel, S.; Schirrmann, T. Selection of recombinant antibodies from antibody gene libraries. Methods Mol. Biol 2007, 408, 243-255.

36. Hust, M.; Steinwand, M.; Al-Halabi, L.; Helmsing, S.; Schirrmann, T.; Dübel, S. Improved microtitre plate production of single chain Fv fragments in Escherichia coli. N. Biotechnol. 2009, 25, 424-428.

37. Schmiedl, A.; Breitling, F.; Winter, C.H.; Queitsch, I.; Dübel, S. Effects of unpaired cysteines on yield, solubility and activity of different recombinant antibody constructs expressed in E. coli. J. Immunol. Methods 2000, 242, 101-114. 
38. Jordan, E.; Hust, M.; Roth, A.; Biedendieck, R.; Schirrmann, T.; Jahn, D.; Dübel, S. Production of recombinant antibody fragments in Bacillus megaterium. Microb. Cell Fact. 2007, 6, 2.

39. Rülker, T.; Meier, D.; Schirrmann, T. Quantification of human IgG and related Fc fusion proteins by a human IgG/Fc capture ELISA. In Antibody Engineering; Kontermann, R., Dübel, S., Eds.; Springer Berlin Heidelberg: Berlin, Germany, 2010; pp. 743-748.

40. Sambrook, J.; Russell, D.W. Molecular Cloning: A Laboratory Manual, 3rd ed.; Cold Spring Harbor Laboratory Press: Cold Spring Harbor, NY, USA, 2001.

41. Blum, H.; Beier, H.; Gross, H.J. Improved silver staining of plant proteins, RNA and DNA in polyacrylamide gels. Electrophoresis 1987, 8, 93-99.

(C) 2012 by the authors; licensee MDPI, Basel, Switzerland. This article is an open access article distributed under the terms and conditions of the Creative Commons Attribution license (http://creativecommons.org/licenses/by/3.0/). 